\title{
Development and Application of Kinetic Spectrophotometric Method for the Determination of Metronidazole
}

\author{
Vojkan M Miljkovic ${ }^{1^{*}}$, Danijela A Kostic ${ }^{2 *}$, Zoran Z Bojanic ${ }^{1}$, Biljana \\ M.Kalicanin ${ }^{1}$, Gordana M Kocic ${ }^{1}$ \\ ${ }^{1}$ Faculty of Medicine, ${ }^{2}$ Faculty of Sciences and Mathematics, The University of Nis, Serbia \\ *For correspondence: Email: vojkanmm_serbia@yahoo.com; Fax: +38118533014
}

\begin{abstract}
Purpose: To develop an improved kinetic-spectrophotometric procedure for the determination of metronidazole (MNZ) in pharmaceutical formulations.

Methods: The method is based on oxidation reaction of MNZ by hydrogen peroxide in the presence of $\mathrm{Fe}(\mathrm{II})$ ions at $\mathrm{pH} 4.5$ (acetate buffer). The reaction was monitored spectrophotometrically by measuring the rate of change of absorbance at $317 \mathrm{~nm}$.

Results: The optimum operating conditions for reagent concentrations and temperature were established. Linear calibration curve was obtained in the range of $85.77-513.45 \mathrm{ng} \mathrm{mL}^{-1}$ with standard deviation from 1.77 to $4.55 \%$-. The optimized conditions yielded a theoretical detection limit of $15.20 \mathrm{ng}$ $\mathrm{mL}^{-1}$ based on $3.3 \mathrm{~S}_{0}$ criterion. Commonly used excipients and other additives such as talc, glucose, fructose, lactose, starch, magnesium stearate, microcrystalline cellulose and several ions were found not to have interference.

Conclusion: The developed method is sensitive, accurate and reproducible and could be used for routine analysis of metronidazole in pharmaceutical preparations.
\end{abstract}

Keywords: Metronidazole, Kinetic spectrometry, Validation, Pharmaceutical preparation.

Tropical Journal of Pharmaceutical Research is indexed by Science Citation Index (SciSearch), Scopus, International Pharmaceutical Abstract, Chemical Abstracts, Embase, Index Copernicus, EBSCO, African Index Medicus, JournalSeek, Journal Citation Reports/Science Edition, Directory of Open Access Journals (DOAJ), African Journal Online, Bioline International, Open-J-Gate and Pharmacy Abstracts

\section{INTRODUCTION}

Metronidazole [2-(2-methyl-5-nitro- 1H- imidazol$1-\mathrm{yl})$ ethanol] is an amebicide, antiprotozoal and antibiotic effective against anaerobic bacteria and certain parasites.[1] It is the drug of choice for first episodes of mild-to-moderate Clostridium difficile infection [2]. Metronidazole exerts rapid bactericidal effects against anaerobic bacteria, with a killing rate proportional to the drug concentration. Concentration-dependent killing has also been observed with Entamoeba histolytica and Trichomonas vaginalis. Metronidazole kills Bacteroides fragilis and
Clostridium perfringens more rapidly than clindamycin $[3,4]$.

Review of literature for MNZ analysis revealed that several existing methods including different techniques such as HPLC with UV detection [57], GC-FID [8], HPLC PDA/MS [9] ,UPLC-MS [10] assay for its quantification in plasma and gastric juice fluids have been reported for assay of metronidazole.

There are UV-Vis spectrophotometric methods for the determination of metronidazole, but they 
are not easy to perform, are not sufficiently sensitive, accurate and selective.

The aim of the present work, therefore, is to develop a simple, sensitive, specific, spectrophotometric method for the detection of MNZ in pharmaceutical tablet formulation, and that does not need sophisticated instruments or special skill, and requires less sample handling than methods currently described in the literature.

\section{EXPERIMENTAL}

\section{Apparatus}

Perkin-Elmer Lambda $15 \quad$ UV/Vis spectrophotometer equipped with kinetic accessory provided with a temperature controlled cell.

\section{Reagents}

Stock solution $\left(1.0 \cdot 10^{-3} \mathrm{~mol} \mathrm{~L}^{-1}\right)$ of metronidazole was prepared in absolute ethanol from MNZ powder (certified purity: $99.92 \%$ ), kindly provided by Galenika, A.D., Belgrade, Serbia. The solution was stored at $4{ }^{\circ} \mathrm{C}$.

Analytical reagent grade chemicals and deionised water (MicroMed high purity water system, TKA Wasseraufbereitungssysteme $\mathrm{GmbH}$ ) were used for the preparation of all solutions. Stock solution of $\mathrm{Fe}(\mathrm{II})\left(1.0 \cdot 10^{-3} \mathrm{~mol} \mathrm{~L}^{-}\right.$ $\left.{ }^{1}\right)$ was prepared by dissolving $\mathrm{FeSO}_{4} \cdot 7 \mathrm{H}_{2} \mathrm{O}$ (Merck) in water. The $\mathrm{pH}$ of the reaction mixture was kept constant by adding acetate buffer prepared by standard procedure.

Hydrogen peroxide solution $\left(0.1 \mathrm{~mol} \mathrm{~L}^{-1}\right)$ was prepared from the $34 \%$ reagent.

All the glassware used were washed with aqueous $\mathrm{HCl}(1: 1)$ and then thoroughly rinsed with running, distilled water, and then finally with deionised water.

\section{General procedure}

In order to obtain good mechanical and thermal stability, the instruments were run for $10 \mathrm{~min}$ prior to the first measurement. The reaction was carried out as follows. In the reaction mixture vessel with four compartments, the solution of MNZ was placed in one compartment, acetate buffer in the second, in the third, $\mathrm{Fe}(\mathrm{II})$, hydrogen peroxide and water (total volume: 10 $\mathrm{mL}$ ) in the fourth compartment

The vessel was thermostated at $25.00 \pm 0.1^{\circ} \mathrm{C}$ and the reaction was initiated by vigorously shaking the reactants. The reaction solution was transferred to a cell, and the absorbance at 317 $\mathrm{nm}$ was measured spectrophotometrically every $30 \mathrm{~s}$ over a period of 5 - $6 \mathrm{~min}$ (after mixing) against the reagent blank prepared similarly. The rate of the reaction $(d c / d t)$ at different concentrations of each of the reactants was obtained by measuring the slope of the linear part of the kinetic curves of the absorbance time plot. Based on Beer's law, Eqs 1 and 2 were derived.

$A=\varepsilon \cdot l \cdot c$

$\operatorname{tg} \alpha=d A / d t=\varepsilon \cdot l \cdot d c / d t$

where $d c$ is the change in the concentration of indicator substances,

$\varepsilon$ is molar absorption coefficient,

I - the thickness of the absorption layer and $d A$ is the change in the absorbance of the indicator substance.

The calibration graph was constructed by plotting the slope of the linear part of the kinetic curve versus the concentration of MNZ [11].

\section{Procedure for tablets}

A total of twenty tablets of each of the different pharmaceutical formulations containing MNZ were weighed and finely powdered using a mortar and pestle. An accurately weighed portion of the resulting powder, equivalent to $10 \mathrm{mg}$ of MNZ, was dissolved in $25 \mathrm{~mL}$ of ethanol. The mixture was centrifuged at $3500 \mathrm{rpm}$ for $5 \mathrm{~min}$, filtered through a $0.45 \mu \mathrm{m}$ membrane filter (Millipore) directly into a $50 \mathrm{~mL}$ volumetric flask and made up to volume with ethanol to obtain a solution of theoretical MNZ concentration of 200 $\mathrm{ngmL}^{-1}$. Aliquots of this solution were transferred into vessels spanning the concentration range listed in Table 4. In all cases, it was assumed that the actual content of the tablet corresponds to the labeled strength of the products.

Data were reported as mean \pm standard deviation (SD) for five determinations. Statistical analysis was performed by Student t-test and Ftest at $95 \%$ confidence level, using a statistical package (Statistica 8.0, StatSoft, Inc, Tulsa, OK, USA) [11].

\section{RESULTS}

\section{Kinetic studies}

A differential variant of the tangent method [12] was used for the processing of the kinetic data because a linear correlation exists between the absorbance at $317 \mathrm{~nm}$ and time during the first 6 min after mixing. In order to determine the lowest possible determinable concentration of MNZ, the 
conditions needed to be optimized. Therefore, the dependencies of the rates of the substrate reactions on the concentration of each of the reactants were determined.

\section{Effect of variables}

Keeping all other experimental parameters constant, the dependence of the reaction rate on $\mathrm{pH}$ in acetate buffer in the range of 3.0-5.0 was studied. The optimal difference between the rates of non-substrate and substrate reactions occurred at $\mathrm{pH} 4.5$ and for further work, this $\mathrm{pH}$ value was selected because at higher $\mathrm{pH}$ values, the rate of both reactions significantly increased and thus, enlarged errors during measurement. For further work, a volume of $1.0 \mathrm{~mL}$ of acetate buffer $\mathrm{pH} 4.5$ was selected as optimal.

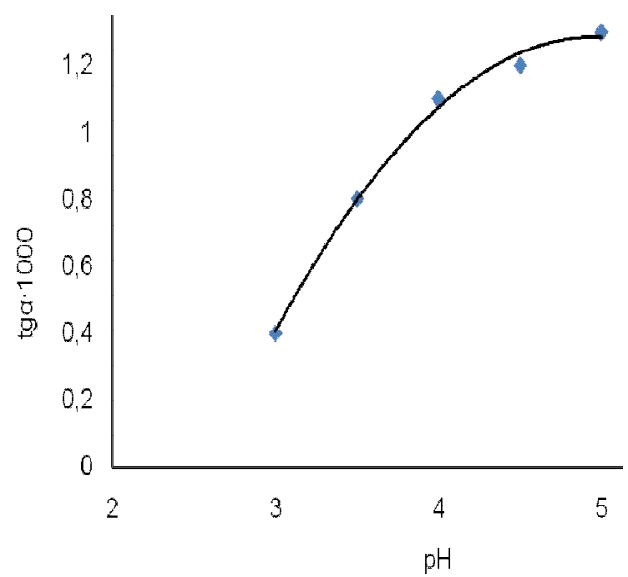

Figure 1: Dependence of reaction rate on $\mathrm{pH}$. Initial concentrations: $C_{M N Z}=2 \times 10^{-7} \mathrm{~mol} \mathrm{~L}^{-1}, C_{\mathrm{Fe}(\mathrm{II})}=1 \times 10^{-6}$ $\mathrm{mol} \mathrm{L}^{-1}, \mathrm{C}_{\mathrm{H} 2 \mathrm{O} 2}=1.96 \times 10^{-3} \mathrm{~mol} \mathrm{~L}^{-1}, t=25 \pm 0.1^{\circ} \mathrm{C}, \lambda=$ $317 \mathrm{~nm}$

The correlation between the reaction rate and $\mathrm{pH}$ was not linear. Thus, the logarithms of tana were calculated and the obtained values were plotted vs $\mathrm{pH}$. From the obtained regression equations, the order of reaction was determined and was 0,3 .

The dependence of reaction rates on the concentrations of $\mathrm{Fe}(\mathrm{II})$ were investigated over the range from $0.5 \times 10^{-5}$ to $2.5 \times 10^{-5} \mathrm{~mol} \mathrm{~L}^{-1}$. For further work, a concentration of $\mathrm{Fe}$ (II) of $1 \times 10^{-5}$ $\mathrm{mol}^{-1} \quad$ was selected as the optimal value, because at higher concentrations absorbance significantly increased $(A>1)$, which also increased the error of the spectrophotometric determination. The rate of substrate reaction was pseudo first order with respect to $\mathrm{Fe}$ (II) concentration.

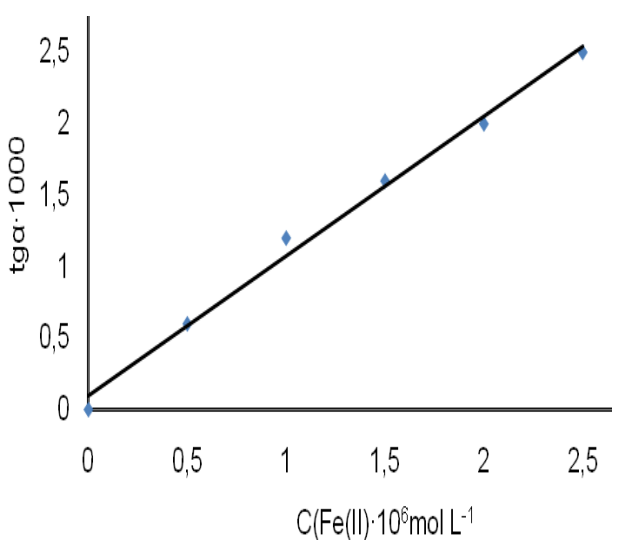

Figure 2: Dependence of reaction rate on $\mathrm{Fe}(\mathrm{II})$ concentration. Initial concentrations: $C_{M N Z}=2 \cdot 10^{-7} \mathrm{~mol}$ $L^{-1}, C_{\mathrm{H} 2 \mathrm{O} 2}=1.96 \times 10^{-3} \mathrm{~mol} \mathrm{~L}^{-1}, \mathrm{pH}=4.5$ (acetate buffer), $t=25 \pm 0.1^{\circ} \mathrm{C}, \lambda=317 \mathrm{~nm}$,

The dependence of reaction rate on concentration of $\mathrm{H}_{2} \mathrm{O}_{2}$ was investigated in the range $0.49 \times 10^{-2}$ to $2.5 \times$ $10^{-2} \mathrm{~mol} \mathrm{~L}^{-1}$.

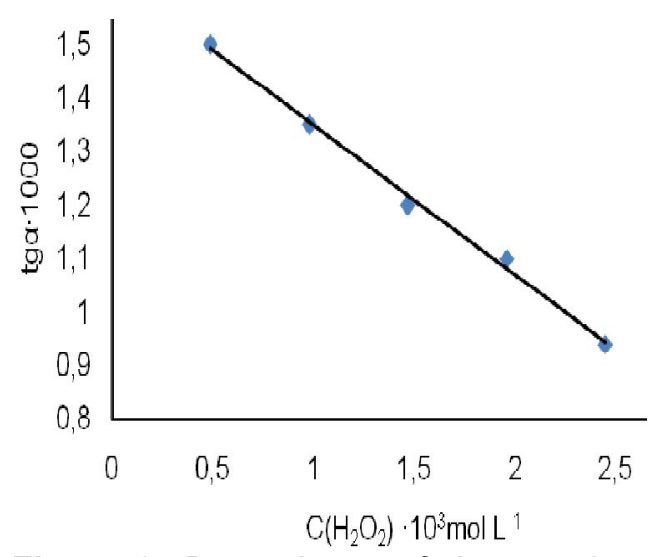

Figure 3: Dependence of the reaction rate on $\mathrm{H}_{2} \mathrm{O}_{2}$ concentration. Initial concentrations: $\mathrm{C}_{M N Z}=$ $2 \times 10^{-7} \mathrm{~mol}^{-1}, \mathrm{pH}=4.5$ (acetate buffer), $C_{\mathrm{Fe}(I I)}=$ $1 \times 10^{-6} \mathrm{~mol} \mathrm{~L}^{-1}, t=25 \pm 0.1^{\circ} \mathrm{C}, \lambda=317 \mathrm{~nm}$

For further work, a concentration of $\mathrm{H}_{2} \mathrm{O}_{2}$ of 1.96 $\times 10^{-3} \mathrm{~mol}^{-1}$, was selected as a suitable value. The reaction rate at that concentration was optimal, and the kinetic curve was linear in the tested interval.

The rate of substrate reaction was $(-1)$ order with respect to $\mathrm{H}_{2} \mathrm{O}_{2}$ concentrations in the investigated interval.

The optimal reaction conditions were:

$\mathrm{pH}=4.5$ (acetate buffer), $\mathrm{C}_{\mathrm{Fe}(\mathrm{II})}=1 \times 10^{-6} \mathrm{~mol} \mathrm{~L}^{-}$ $\dot{\mathrm{C}}_{\mathrm{H} 2 \mathrm{O} 2}=1.96 \times 10^{-3} \mathrm{~mol} \mathrm{~L} L^{-1}, \quad \mathrm{t}=25 \pm 0.1^{\circ} \mathrm{C}$, $\lambda=317 \mathrm{~nm}$.

MNZ concentrations were varied from 85.77 to $513.45 \mathrm{ng} \mathrm{mL}^{-1}$, and a linear dependence was established between $\operatorname{tg} \alpha$ and the concentration of MNZ . [12]

$$
\operatorname{tg} \alpha=0.003 C_{M N Z}-0.017, \quad R^{2}=0.998
$$


where tga is the slope of the linear part of the kinetic curve of the absorbance-time plot; $C_{\mathrm{MNZ}}$ is concentration of MNZ expressed as $\mathrm{ng} \mathrm{mL}^{-1}$ and $R$ is correlation coefficient. This equation was used for the determination of MNZ concentration in the interval mentioned.

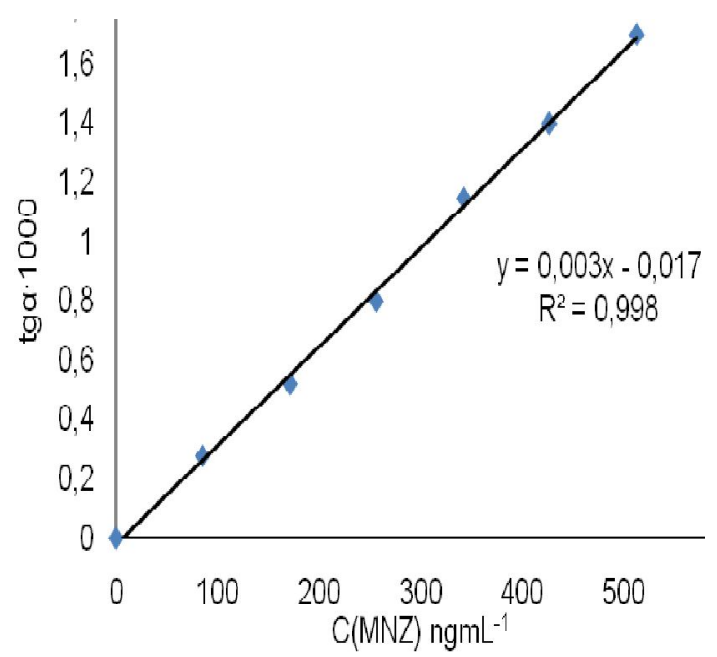

Figure 4: Dependence of reaction rate on $t M N Z$ concentration. Initial concentrations: $\mathrm{pH} 4.5$ (acetatni pufer), $C_{\mathrm{Fe}(\mathrm{II})}=2 \times 10^{-6} \mathrm{~mol} \mathrm{~L}^{-1}, C_{\mathrm{H} 2 \mathrm{O} 2}=1,96 \times 10^{-3} \mathrm{~mol}$ $L^{-1}, t=25 \pm 0.1^{\circ} \mathrm{C}, \lambda=317 \mathrm{~nm}$.

The kinetic equation ( $\mathrm{Eq} 3$ ) for the reaction was deduced on the basis of the kinetics of the indicator reaction proposed.[13]

$-\frac{d c}{d t}=k \cdot c_{H^{+}}^{-0,3} \cdot c_{F e(I I)}^{1} \cdot c_{H_{2} O_{2}}^{-1} \cdot c_{M N Z}^{1}$

where $\mathrm{k}$ is the constant proportional to the rate constant of the reaction.

\section{Parameter value}

The limit of detection (LOD) [14] was evaluated using Eq 6.

$$
c_{L}=\frac{3.3 \cdot S_{o}}{m}
$$

where $S_{0}$ is the residual standard deviation of the calibration line, and $\mathrm{m}$ is the slope of the calibration line (analytical sensitivity). LOD was found to be $15.20 \mathrm{ng} \mathrm{mL}$. The limit of quantification (LOQ) was evaluated using Eq 7.

$$
c_{Q}=\frac{10 \cdot S_{o}}{m}
$$

It was found to be $45.6 \mathrm{ng} \mathrm{mL}-1$. The LOD value indicates that the method was sensitive. The precision and accuracy of the proposed method was studied by performing the experiment five times at three different concentration levels (low, medium and high) of MNZ. The results are shown in Table 1.
Table 1: Accuracy and precision of the proposed method

\begin{tabular}{llllll}
\hline $\begin{array}{l}\text { Taken } \\
(\mathbf{n g} \\
\mathbf{m L}\end{array}$ & $\begin{array}{l}\text { Found } \\
\mathbf{( n g}\end{array}$ & $\begin{array}{l}\mathbf{N} \\
\left.\mathbf{m L}^{-1}\right)\end{array}$ & SD\% & RSD\% & $\frac{\bar{x}-\mu}{\mu} \cdot 100 \%$ \\
\hline 513.45 & 506.5 & 5 & 1.45 & 1.77 & 4.16 \\
\hline 171.54 & 168.83 & 5 & 2.21 & 3.22 & 1.58 \\
\hline 85.77 & 82.21 & 5 & 0.84 & 4.55 & 1.35 \\
\hline
\end{tabular}

Found- mean value; taken- true value, N-number of determinations; SD-. standard deviation, RSDrelative standard deviation, accuracy of method

$$
\frac{\bar{x}-\mu}{\mu} \cdot 100 \%
$$

\section{Interference studies}

To assess the selectivity of the method, a systematic study of the possible interferences by species accompanying MNZ in pharmaceuticals was carried out. The criterion of interference was fixed at $5 \%$ variation of the average slope change measured $(n=5)$ for the established level of MNZ. The tolerance limits (expressed as $w / w$ ratio) for the species studied on the determination of $171.54 \mathrm{ng} \mathrm{mL} \mathrm{mL}^{-1}$ of $\mathrm{MNZ}$ are given in Table 2.

Table 2: Tolerance ratio for foreign species in the

\begin{tabular}{|c|c|}
\hline $\begin{array}{l}\text { Tolerance level } \\
\mathrm{C}_{\mathrm{x}} / \mathrm{C}_{\mathrm{MNZ}}\end{array}$ & Foreign species \\
\hline 100 & $\begin{array}{l}\mathrm{Na}^{+}, \mathrm{K}^{+}, \mathrm{Ni}^{2+}, \mathrm{Fe}^{2+}, \mathrm{Mg}^{{ }^{2+}}{ }^{{ }^{+}}, \\
\mathrm{Ca}^{2+}, \mathrm{NO}_{3}{ }^{-}, \mathrm{CH}_{3} \mathrm{COO}^{-}, \mathrm{CO}_{3}{ }^{2-}, \mathrm{Cl}\end{array}$ \\
\hline 100 & $\begin{array}{l}\text { talc,glucose, fructose, lactose, } \\
\text { starch, magnesium stearate, } \\
\text { microcrystalline cellulose }\end{array}$ \\
\hline 10 & $\begin{array}{l}\mathrm{Se}^{4+}, \mathrm{Cd}^{2+}, \mathrm{Mn}^{2+}, \mathrm{Pb}^{2+}, \mathrm{Cu}^{2+}, \\
\mathrm{Br}^{-}, \mathrm{SO}_{4}{ }^{2-},\end{array}$ \\
\hline 1interfere & $\begin{array}{l}\text { ascorbic acid, citric acid, } \\
\text { doxicyclin, streptomycin, }\end{array}$ \\
\hline
\end{tabular}
determination of $\mathrm{MNZ}\left(171.54 \mathrm{ng} \mathrm{mL}^{-1}\right.$ ) under optimal conditions.

Commonly used excipients and other additives such as talc, glucose, fructose, lactose, starch, magnesium stearate, microcrystalline cellulose and several ions were found to have no interference. More severe interference was observed for ascorbic acid, citric acid and other antibiotics in the ratio $1: 1$.

\section{Applicability of the proposed method}

In order to test the analytical validity of the proposed method, it was applied to the 
Table 3: Determination of MNZ in commercial tablet formulation by the proposed method (kinetic) and standard potentiometric) methods

\begin{tabular}{|c|c|c|c|c|c|c|c|c|}
\hline $\begin{array}{l}\text { Pharma- } \\
\text { ceutical } \\
\text { prep. }\end{array}$ & $\begin{array}{l}\text { Found MNZ } \\
\text { kinetic meth. } \\
\left(\text { ng mL }^{-1}\right)\end{array}$ & $\begin{array}{l}\text { RSD } \\
(\%)\end{array}$ & $\begin{array}{l}\text { Reco } \\
\text { very } \\
(\%)\end{array}$ & $\begin{array}{l}\text { Found MNZ } \\
\text { Standard meth } \\
\left(\mathrm{ng} \mathrm{mL} \mathrm{m}^{-1}\right)\end{array}$ & $\begin{array}{l}\text { RSD } \\
(\%)\end{array}$ & $\begin{array}{l}\text { Reco } \\
\text { very } \\
(\%)\end{array}$ & F-test & t-test \\
\hline $\begin{array}{l}\text { Flagil } \\
\text { Orvagil } \\
\text { MNZ } \\
\text { Normon }\end{array}$ & $\begin{array}{l}198.63 \pm 2.30 \\
197.25 \pm 3.12 \\
197.83 \pm 2.86\end{array}$ & $\begin{array}{l}1.18 \\
1.56 \\
1.43\end{array}$ & $\begin{array}{l}98.20 \\
97.76 \\
98.54\end{array}$ & $\begin{array}{l}198.80 \pm 2.06 \\
198.71 \pm 2.26 \\
198.65 \pm 2.48\end{array}$ & $\begin{array}{l}1.03 \\
1.13 \\
1.24\end{array}$ & $\begin{array}{l}97.89 \\
98.35 \\
99.20\end{array}$ & $\begin{array}{l}3.26 \\
3.59 \\
4.02\end{array}$ & $\begin{array}{l}1.83 \\
1.73 \\
2.06\end{array}$ \\
\hline
\end{tabular}

Table 4: Comparison of proposed method with existing spectrophotometric methods

\begin{tabular}{|c|c|c|c|c|}
\hline Method & Reagents & $\Lambda_{\max }$ & Restriction of method & Ref \\
\hline 1 & $\begin{array}{l}\text { 3-Methyl benzothiazolin-2-one } \\
\text { hydrazone (MBTH) }\end{array}$ & 500 & MBTH is costly reagent & [16] \\
\hline 2 & $\begin{array}{l}\text { N-1-naphthyl-ethylenediamine } \\
\text { dihydrochloride } \\
\text { (NEDA) }\end{array}$ & 520 & $\begin{array}{l}\text { Involves the addition step of } \\
\text { diazotization }\end{array}$ & [16] \\
\hline 3 & $p$-Dimethylaminocinnamaldehyde & 510 & $\begin{array}{l}\text { Condenzation reaction is time } \\
\text { consuming }\end{array}$ & [17] \\
\hline 4 & $\beta$-Naphthol & 480 & $\begin{array}{l}\text { Three step procces:reduction, } \\
\text { diazotization, coupling }\end{array}$ & [18] \\
\hline 5 & Metal and $\mathrm{K}_{2} \mathrm{Cr}_{2} \mathrm{O}_{7}$ & 502 & $\begin{array}{l}\text { Involves reduction by } \mathrm{Zn}-\mathrm{HCl} \\
\text { at } \mathrm{pH} 2,9 \text {. Color formation and } \\
\text { stability depend of } \mathrm{pH} \text { value }\end{array}$ & [19] \\
\hline 6 & $\begin{array}{l}\text { NN-dimethyl-p-phenylenediamine } \\
\text { and chloramine-T }\end{array}$ & 540 & $\begin{array}{l}\text { Involves reduction by } \mathrm{Zn}-\mathrm{HCl} \\
\text { at } \mathrm{pH} \text {. Color formation and } \\
\text { stability depend of } \mathrm{pH} \text { value }\end{array}$ & [20] \\
\hline 7 & Bromocresol green & 654 & $\begin{array}{l}\text { Involves extraction with } \mathrm{CHCl}_{3} \text {, } \\
\text { at } \mathrm{pH} 9,5\end{array}$ & [21] \\
\hline 8 & Bromocresol green purple & 618 & $\begin{array}{l}\text { Involves extraction with } \mathrm{CHCl}_{3} \\
\text { at } \mathrm{pH} 10\end{array}$ & [21] \\
\hline 9 & 8-Quinolinol & 500 & $\begin{array}{l}\text { Reagent is costly and not easily } \\
\text { available. }\end{array}$ & [22] \\
\hline 10 & $p$-Benzoquinone & 526 & $\begin{array}{l}\text { Two step proces,reagens is } \\
\text { cheep and easily available }\end{array}$ & [23] \\
\hline 11. & This work & 317 & $\begin{array}{l}\text { Fast, one step proces, high } \\
\text { sensitivity, UV-detection }\end{array}$ & \\
\hline
\end{tabular}

determination of MNZ in pharmaceutical DISSCUSION

formulations.

The results of the proposed method were statistically compared with those of the standard potentiometric method [15] using a point hypothesis test.

Statistical analysis of the results (Tables 3.) showed that calculated F- and t-values at $95 \%$ confidence levels were less than the theoretical ones, confirming no significant differences between the performance of the proposed and the standard potentiometric method. Therefore, the proposed method could be used for the determination of MNZ in pharmaceutical preparations.
The method is based on the reaction of MNZ by hydrogen peroxide in acetate buffer $(\mathrm{pH} 4.5)$, in the presence of $\mathrm{Fe}(\mathrm{II})$, which acted as a catalyst. The reaction was monitored spectrophotometrically by measuring the absorbance of formed product at $317 \mathrm{~nm}$.

Under optimal conditions $(\mathrm{pH} 4.5$ (acetate buffer), $\mathrm{C}_{\mathrm{Fe}(\mathrm{II})}=1 \times 10^{-6} \mathrm{~mol} \mathrm{~L} L^{-1}, \mathrm{C}_{\mathrm{H} 2 \mathrm{O} 2}=$ $\left.1.96 \cdot 10^{-3} \mathrm{~mol} \mathrm{~L}^{-1}, \mathrm{t}=25 \pm 0.1{ }^{\circ} \mathrm{C}, \lambda=317 \mathrm{~nm}\right)$, the method showed statisfactory standard deviation and relative standard deviation (from 1.77 to $4.55 \%$ ), respectively. Least-squares regression analysis used to evaluate the concentration range data indicates linearity over the interval studied $\left(85.77 \mathrm{ng} \mathrm{mL}^{-1}\right.$ to $513.45 \mathrm{ng}$ $\mathrm{mL}^{-1}$ ). The correlation coefficient obtained for this MNZ concentration range was 0.998 . The LOD 
value of $15.20 \mathrm{ng} \mathrm{mL}^{-1}$ indicates that the method is sensitive. Commonly used excipients and many investigated ions were found to have no interference.

The results of the proposed method were statistically compared with those of the standard potentiometric method method using a point hypothesis test. Statistical analysis of the results showed that calculated F- and t-values at $95 \%$ confidence levels were less than the theoretical ones, confirming no significant differences between the performance of the proposed and the standard method. Therefore, the proposed method could be used for the determination of metronidazole in pharmaceutical preparations. A comparison of the present method with the existing spectrophotometric methods is given in Table 4. This demonstrates the advantages of the proposed method.

\section{CONCLUSION}

The proposed kinetic-spectrophotometric method for the determination of MNZ in pharmaceutical samples reported in this work is simple, fast, inexpensive, and thus appropriate for routine quality control analysis of the active drug in the laboratories of hospitals, pharmaceutical industries and research institutions. It should also be suitable for developing countries. The validation of the method shows that the results obtained are in good agreement with the potentiometric method.

\section{ACKNOWLEDGEMENT}

This research was supported by grant no. 142047 and no. 34012 from the Serbian Ministry of Education and Science.

\section{REFERENCES}

1. The Merck Index, 11th edn, Merck and Co Inc, Rahway, USA 6181, 2001.

2. Heisterberg L, Branebjerg PE Blood and milk concentrations of metronidazole in mothers and infants. J Perinat Med1983; 11(2):114-118

3. Marchioretto MAM., Ecclissato C, Cassiano NM, Mendonça S, Bernasconi GCR. Plasma hydroxymetronidazole/metronidazole ratio in hepatitis $C$ virus-induced liver disease. Brazilian J. Med Biol Res 2005;(38): 437-444

4. The Martindale, 35th edn "The Complete drug reference", 2006, The Pharmaceutical Press, London

5. Kaye CM, Sankey MJ, Thomas $L A$. A rapid and specific semi-micro method involving high-pressure liquid chromatography for the assay of metronidazole in plasma, saliva, serum, urine and whole blood. Brit J Clin Pharmacol 1980;9(5): 528-529.
6. Ezzeldin E, El-Nahhas TM. New analytical method for the determination of metronidazole in human plasma: Application to bioequivalence study. Trop J Pharm Res 2012; 11(5): 799-805

7. Mustapha KB, Odunola MT, Garba M, Obodozie $O$. Rapid, cost-effective liquid chromatograghic method for the determination of metronidazole in biological fluids. Afr J Biotechnol 2006;5 (13):11881190

8. Ashour S, Kattan N. Simultaneous determination of miconazole nitrate and metronidazole in different pharmaceutical dosage forms by gas chromatography and flame ionization detector (GCFID). Int J Biomed Sci. 2010; 6(1): 13-19

9. Wang $P$, Li-Jie, Zheng $H$, Simultaneous determination of seven sulfonamides and metronidazole and chloramphenicol in cosmetics by high performance liquid chromatography. Chin J Chrom 2007; 5: 743-746

10. Liu H, Li F, Yang R, Wang L, Ma Y Determination of common antibiotics and metronidazole in cosmetics by ultra performance liquid chromatography-tandem mass spectrometry. Chin J Chrom 2009; 27(1): 50-53

11. Statistical Analysis and Reporting System, Ser Guide, version 1.0, 1MB, 1999.

12. Miller JN. Basic statistical methods for analytical chemistry. Part 2. Calibration and regression methods. Analyst 1991; 116(1): 3-14

13. Ermer J. Validation in pharmaceutical analysis. Part I: An integrated approach. J Pharm Biomed Anal 2001; 24(5-6): 755-767

14. Hammond GS. A correlation of reaction rate. $J A m$ Chem Soc1955; 77(2): 334-338

15. British Pharmacopoeia, vol. II. Her Majesty's Stationery Office, London, 2003; $p 1257$.

16. Nagaraja $P$, Sunitha KR, Vasantha RA, Yathirajan HS. Spectrophotometric determination of metronidazole and tinidazole in pharmaceutical preparations. J Pharm Biomed Anal 2002;28(3-4): 527-535

17. Moussa BA. Colorimetric determination of parasiticides hycanthone and metronidazole. Int J Pharm 1982; 10(3): 199-207

18. Gandhi TP, Patel PR, Patel VC, Patel SK, Colonnietric estimation of rifampicin in formulalions and biological fluids by metallic ions. J I Chem 1984; 56: $127-128$

19. Sastry CSP, Aruna M, Rao ARM. Spectrophotometric determination of some antiamoebic and anthelmintic drugs with metol and chromium(VI). Talanta 1988; 35(1): 23-26

20. Sastry CSP, Aruna $M$, Rao ARM. Tipirneni ASRP. Application of $P N, N$-dimethylphenylenediamine dihydrochloride for the determination of some antiamoebic and anthelmintic drugs. Chem Anal 1991; 36: 153-157

21. Amin AS. Quantitative determination of some pharmaceutical veterinary formulations using bromocresol purple and bromocresol green. Anal Lett 1997; 30(14) :2503-2513

22. Saffaj $T$, Charrouf $M$, Abourriche A, Abboud $Y$, Bennamara $A$, Berrada $M$, Spectrophotometric determination of metronidazole and secnidazole in pharmaceutical preparations. II Farmaco 2004; 59(10): 843-846

23. Atta-ur-Rehman, Ijaz AS, Raza A. Spectrophotometric determination of metronidazole in pharmaceutical pure and dosage forms using p-benzoquinone. $J$ Iran Chem Soc. 2005;2(3): 197-202. 